\title{
Electrical conductivity of solid solution of Co(II)-Zn dihydrophosphate and its thermolysis products
}

\author{
N.M.Antraptseva, N.V.Solod, V.A.Povshuk \\ National University of Life and Environmental Sciences of Ukraine, \\ 17 Heroev Oborony St., 03041 Kyiv, Ukraine
}

Received April 04, 2015

\begin{abstract}
Dependence of the specific electrical conductivity value of the solid solution with composition $\mathrm{Co}_{1-x} \mathrm{Zn}_{x}\left(\mathrm{H}_{2} \mathrm{PO}_{4}\right)_{2} \cdot 2 \mathrm{H}_{2} \mathrm{O}(0<x<1.0)$ and products of its partial or complete dehydration from temperature and duration of heat treatment has been investigated. It has been established that they have considerable proton conductivity (from $1.01 \cdot 10^{-2}-$ $1.18 \cdot 10^{-2} \mathrm{Ohm}^{-1} \mathrm{~cm}^{-1}$ to $7.51 \cdot 10^{-3}-9.57 \cdot 10^{-3} \mathrm{Ohm}^{-1} \mathrm{~cm}^{-1}$ ) in a wide temperature range $\left(80-270^{\circ} \mathrm{C}\right)$. The main contribution to their proton conductivity has made mobile protons of the phosphate anion $\mathrm{P}-\mathrm{OH}$ groups and free phosphoric acid protons, which have produced in the intermediate thermolysis products according to PMR and ${ }^{31} \mathrm{P} N M R$ spectrum analysis of $\mathrm{Co}(\mathrm{II})-\mathrm{Zn}$ dihydrophosphates heat treatment products. Contribution of crystal water protons is minimal.
\end{abstract}

Keywords: electrical conductivity, phosphates, solid solution, thermolysis.

Изучена зависимость величины удельной электропроводности твердого раствора $\mathrm{Co}_{1-x} \mathrm{Zn}_{x}\left(\mathrm{H}_{2} \mathrm{PO}_{4}\right)_{2} \cdot 2 \mathrm{H}_{2} \mathrm{O}(0<x<1.0)$ и продуктов его частичного и полного обезвоживания от температуры и продолжительности термообработки. Установлено, что они обладают значительной протонной проводимостью (от $1.01 \cdot 10^{-2}-1.18 \cdot 10^{-2} \mathrm{OM}^{-1} \mathrm{~cm}^{-1}$ до $\left.7.51 \cdot 10^{-3}-9.57 \cdot 10^{-3} \mathrm{OM}^{-1} \mathrm{~cm}^{-1}\right)$ в широкой температурной области $\left(80-270^{\circ} \mathrm{C}\right)$. Анализ спектров ПМР и ЯМР ${ }^{31} \mathrm{P}$ продуктов термообработки Сo(II)-Zn дигидрофосфатов показал, что основной вклад в их протонную проводимость вносят подвижные протоны груп $\mathrm{P}-\mathrm{OH}$ фосфатного аниона и протоны свободной фосфорной кислоты, образующиеся в промежуточных продуктах термолиза. Вклад протонов кристаллогидратной воды минимальный.

Електропровідність твердого розчину Co(II)-Zn дигідрогенфосфатів i продуктів його термолізу. Н.М.Антрапцева, Н.В.Солод, В.А.Повшук.

Досліджено залежність величини питомої електропровідності твердого розчину $\mathrm{Co}_{1-x} \mathrm{Zn}_{x}\left(\mathrm{H}_{2} \mathrm{PO}_{4}\right)_{2} \cdot 2 \mathrm{H}_{2} \mathrm{O}(0<x<1.0)$ і продуктів його часткового і повного зневоднення від температури і тривалості термообробки. Встановлено, що вони володіють значною протонною провідністю (від 1.01·10 $-1.18 \cdot 10^{-2} \mathrm{Oм}^{-1} \mathrm{~cm}^{-1}$ до $7.51 \cdot 10^{-3}-9.57 \cdot 10^{-3} \mathrm{OM}^{-1} \mathrm{~cm}^{-1}$ ) у широкому температурному інтервалі $\left(80-270^{\circ} \mathrm{C}\right)$. Аналіз спектрів ПМР и ЯМР ${ }^{31} \mathrm{P}$ продуктів термообробки Co(II)-Zn дигідрогенфосфатів показав, що основний вклад в їх протонну провідність вносять рухливі протони груп Р-OH фосфатного аніона і протони вільної фосфатної кислоти, що утворюються у проміжних продуктах термолізу. Вклад протонів кристалогідратної води мінімальний. 


\section{Introduction}

Solids having low values of resistivity and having unipolar conductivity (solid electrolytes) are widely used in electrochemical systems of various purposes: information converters, gas analyzers, chemical power sources and others [1,2].

The most prospective conducting proton electrolytes are phosphates containing a $\mathrm{P}-\mathrm{OH}$ group, protons of which make the main contribution to the conductivity of solid electrolytes. According to [3, 4], protonated phosphates can be considered as proton conductors. Free protons - carriers of electric current appear inside crystal lattices of protonated by heating above a certain temperature.

From this perspective, practical interest care solid solutions of dihydrophosphates of divalent metals, in the products of thermal treatment of which formations of free phosphoric acid are found [5, 6]. As for electrical conductivity of solid solution of cobalt(II)-zinc dihydrophosphates, information in the literature is absent.

The purpose of this work is to study dependence of electrical conductivity of solid solution of composition of dihydrophosphate $\mathrm{Co}_{1-x} \mathrm{Zn}_{x}\left(\mathrm{H}_{2} \mathrm{PO}_{4}\right)_{2} \cdot 2 \mathrm{H}_{2} \mathrm{O} \quad(0<x<1.0)$ and products of its thermolysis on temperature and duration of heat treatment.

\section{Experimental}

The solid solution of dihydrophosphates of a general formula $\mathrm{Co}_{1-x} \mathrm{Zn}_{x}\left(\mathrm{H}_{2} \mathrm{PO}_{4}\right)_{2} \cdot 2 \mathrm{H}_{2} \mathrm{O}$ $(0<x<1.0)$ was obtained due to reaction of mechanically homogenized mixture of zinc and cobalt(II) hydroxocarbonates, taken in predetermined molar ratio with $\mathrm{H}_{3} \mathrm{PO}_{4}$ $\left(64.1 \% \mathrm{P}_{2} \mathrm{O}_{5}\right)$, as it was described in [7]. Dihydrophosphate of composition $\mathrm{Co}_{0.5} \mathrm{Zn}_{0.5}\left(\mathrm{H}_{2} \mathrm{PO}_{4}\right)_{2} \cdot 2 \mathrm{H}_{2} \mathrm{O}$ was used as a basic object of study.

Conductivity measurements were performed using AC-bridge of P-568 at frequency of $10 \mathrm{kHz}$. Using the distribution terminal ( $50 \%$ of the original sample, $50 \%$ of fine silver), the sample was pressed into tablet with parameters $l=0.1 \mathrm{~cm}, S=0.816 \mathrm{~cm}^{2}$. The tablet was placed in a pressure cell type made out of alloys resistant to acidic corrosion, and it was heated at 1.0 degrees/min. The measurements and calculations were performed as it as described in $[1,4]$.

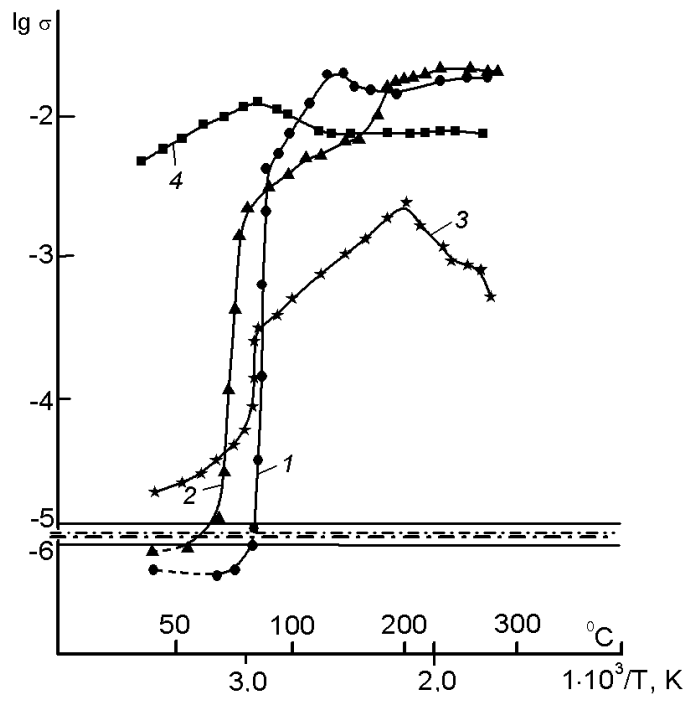

Fig. 1. Polytherms of electrical conductivity of $\mathrm{Co}_{1-x} \mathrm{Zn}_{x}\left(\mathrm{H}_{2} \mathrm{PO}_{4}\right)_{2} \cdot 2 \mathrm{H}_{2} \mathrm{O}$ (1) and its dehydration products obtained at $20^{\circ} \mathrm{C}$ over $\mathrm{P}_{2} \mathrm{O}_{5}$ (2) and $300^{\circ} \mathrm{C}(3,4)$ (3 - dehydrated sample was stored in a dry atmosphere, 4 - in a humid atmosphere).

\section{Results and discussion}

According to polytherm of conductivity of air-dried $\mathrm{Co}_{0.5} \mathrm{Zn}_{0.5}\left(\mathrm{H}_{2} \mathrm{PO}_{4}\right)_{2} \cdot 2 \mathrm{H}_{2} \mathrm{O}$ (Fig. 1), the initial electrical conductivity by heating up $80^{\circ} \mathrm{C}$ change slighly and doesn't exceed the value characteristic of the ionic crystal.

Further increase in temperature leads to fast increase 0 of electrical conductivity. The most significant its changes are fixed under heating up to $85-90^{\circ} \mathrm{C}$ (Table 1 ). Conductivity of $\mathrm{Co}_{0.5} \mathrm{Zn}_{0.5}\left(\mathrm{H}_{2} \mathrm{PO}_{4}\right)_{2} \cdot 2 \mathrm{H}_{2} \mathrm{O}$ heated up to $140^{\circ} \mathrm{C}$ reaches its maximum value $\left(2.01 \cdot 10^{-2} \mathrm{Ohm}^{-1} \mathrm{~cm}^{-1}\right)$, then at the temperature of $150-200^{\circ} \mathrm{C}$ it significantly reduces (up to $1.50 \cdot 10^{-2} \mathrm{Ohm}^{-1} \mathrm{~cm}^{-1}$ ) and increases again at $260^{\circ} \mathrm{C}\left(2.11 \cdot 10^{-2} \mathrm{Ohm}^{-1} \mathrm{~cm}^{-1}\right)$. In the sample heated above $300^{\circ} \mathrm{C}$, the conductivity value is reduced substantially to value recorded for the initial dihydrophosphate. This temperature changes of conductivity of $\mathrm{Co}_{0.5} \mathrm{Zn}_{0.5}\left(\mathrm{H}_{2} \mathrm{PO}_{4}\right)_{2} \cdot 2 \mathrm{H}_{2} \mathrm{O}$ show on the complex physical and chemical processes under the heat treatment and correlate well with the results of its study of thermolysis, described in [6].

Interpretation of the data performed in regard to [6] and the structural features of $\mathrm{Co}_{0.5} \mathrm{Zn}_{0.5}\left(\mathrm{H}_{2} \mathrm{PO}_{4}\right)_{2} \cdot 2 \mathrm{H}_{2} \mathrm{O}$ [8] indicates that increase of the electrical conductivity at $85-90^{\circ} \mathrm{C}$ is associated with breaking of hydrogen bonds that $\mathrm{OH}$-groups of water mole- 
cules and protonated anion are closely connected to the structure of the original dihydrophosphate. Further heating (up to $140^{\circ} \mathrm{C}$ ) leads to destruction of $\mathrm{Co}_{0.5} \mathrm{Zn}_{0.5}\left(\mathrm{H}_{2} \mathrm{PO}_{4}\right)_{2} \cdot 2 \mathrm{H}_{2} \mathrm{O}$ structure and formation of amorphous intermediates products of the heat treatment of free phosphoric acid that is a carrier of mobile protons, that are responsible for appearance of the electric current in the sample. Some decrease in the values of $\sigma$, marked at $200^{\circ} \mathrm{C}$, corresponds to the transition from the inside structural disorder to the ordering of the new generated crystalline phase. Movement of protons here is limited. Furthermore, the amount of phosphoric acid and, as a result, the mobile protons in the products of dihydrophosphate heating treatment above $200^{\circ} \mathrm{C}$ is reduced and it is completely absent in dehydrated phosphate [6]. Such a state of the sample corresponds to decrease in the electrical conductivity at temperature above $300^{\circ} \mathrm{C}$.

To determine the contribution of free phosphoric acid in proton mobility there were analyzed PMR spectrums of heat treatment products of Co(II)-Zn dihydrophosphates of different composition. The results showed that at the room temperature, when the protons are localized, location and shape of the broad lines of the PMR spectrum of $\mathrm{Co}_{1-x} \mathrm{Zn}_{x}\left(\mathrm{H}_{2} \mathrm{PO}_{4}\right)_{2} \cdot 2 \mathrm{H}_{2} \mathrm{O}$ with $x=0.33,0.5$, 0.67 are caused mainly by magnitude of the interproton distance and paramagnetic ion presence. During the heat treatment of the sample in the range of $90-150^{\circ} \mathrm{C}$ the line narrowing of protons of phosphate anion is observed in the spectrums. Minimum value of its width $\left(\Delta H=0.6 \cdot 10^{-4} \mathrm{~T}\right)$ is fixed at $140^{\circ} \mathrm{C}$. Analysis of the temperature changes of the width of this line showed that at the temperature of $120-200^{\circ} \mathrm{C}$ protons are in the state of rapid diffusional mobility. This temperature (shown previously in [6]) corresponds to formation of the products of the heat treatment of $\mathrm{Co}_{1-x} \mathrm{Zn}_{x}\left(\mathrm{H}_{2} \mathrm{PO}_{4}\right)_{2} \cdot 2 \mathrm{H}_{2} \mathrm{O}$ of the maximum amount of free phosphoric acid.

To elucidate the nature of the narrow component appearing in the samples PMR spectra by heating, and validation of assignment it to formation in dihydrophosphates structure free phosphoric acid which protons have high mobility, there were studied NMR ${ }^{31} \mathrm{P}$ spectrums of $\mathrm{CO}_{0.5} \mathrm{Zn}_{0.5}\left(\mathrm{H}_{2} \mathrm{PO}_{4}\right)_{2} \cdot 2 \mathrm{H}_{2} \mathrm{O}$ and products of its heat treatment. Based on the received data it has been established the relationship between the line width of the NMR ${ }^{31} \mathrm{P}$ spectrum and the intensity of the
Table 1. Polytherms of electrical conductivity of $\mathrm{Co}_{0.5} \mathrm{Zn}_{0.5}\left(\mathrm{H}_{2} \mathrm{PO}_{4}\right)_{2} \cdot 2 \mathrm{H}_{2} \mathrm{O}$ and products of its thermolysis (heating rate 1.0 degrees $/ \mathrm{min}$ )

\begin{tabular}{|c|c|c||}
\hline $\begin{array}{c}\text { The heating } \\
\text { temperature, }{ }^{\circ} \mathrm{C}\end{array}$ & $R, \mathrm{Ohm}$ & $\sigma, \mathrm{Ohm}^{-1} \mathrm{~cm}^{-1}$ \\
\hline 25 & $2.7 \cdot 10^{5}$ & $4.53 \cdot 10^{-7}$ \\
35 & $2.2 \cdot 10^{5}$ & $4.53 \cdot 10^{-7}$ \\
45 & $1.7 \cdot 10^{5}$ & $5.57 \cdot 10^{-7}$ \\
50 & $2.6 \cdot 10^{5}$ & $7.20 \cdot 10^{-7}$ \\
60 & $3.3 \cdot 10^{5}$ & $4.71 \cdot 10^{-7}$ \\
70 & $3.0 \cdot 10^{5}$ & $4.08 \cdot 10^{-7}$ \\
80 & $3.9 \cdot 10^{4}$ & $3.14 \cdot 10^{-6}$ \\
85 & 43.0 & $3.61 \cdot 10^{-3}$ \\
90 & 29.0 & $4.22 \cdot 10^{-3}$ \\
100 & 18.0 & $6.80 \cdot 10^{-3}$ \\
110 & 12.0 & $1.02 \cdot 10^{-2}$ \\
120 & 11.6 & $1.06 \cdot 10^{-2}$ \\
130 & 6.2 & $1.97 \cdot 10^{-2}$ \\
140 & 6.1 & $2.01 \cdot 10^{-2}$ \\
150 & 7.1 & $1.72 \cdot 10^{-2}$ \\
160 & 7.5 & $1.63 \cdot 10^{-2}$ \\
180 & 8.0 & $1.53 \cdot 10^{-2}$ \\
200 & 7.22 & $1.50 \cdot 10^{-2}$ \\
220 & 6.5 & $1.88 \cdot 10^{-2}$ \\
240 & 6.3 & $1.94 \cdot 10^{-2}$ \\
260 & 5.8 & $2.11 \cdot 10^{-2}$ \\
\hline
\end{tabular}

narrow component lines in the PMR spectra of the same thermolysis products (Fig. 2). Results of the comparative analysis showed that the appearance of the narrow line in the PMR spectra (the sample heated up to $120^{\circ} \mathrm{C}$ ) correlates with decrease in width and the second point in the line in the NMR ${ }^{31} \mathrm{P}$ spectra. In the NMR spectrum the narrow band of intense is observed, broadens as the fall of the intensity of the narrow component in the PMR spectrum when heated $\mathrm{Co}_{0.5} \mathrm{Zn}_{0.5}\left(\mathrm{H}_{2} \mathrm{PO}_{4}\right)_{2} \cdot 2 \mathrm{H}_{2} \mathrm{O}$ up to $250^{\circ} \mathrm{C}$ and $300^{\circ} \mathrm{C}$. Narrowing of the components in the NMR spectrum can be characterized as formation of the new phase comprising movable phosphorus and presence of the mobile protons.

In addition to the temperature ranges of the high proton conductivity of $\mathrm{Co}_{0.5} \mathrm{Zn}_{0.5}\left(\mathrm{H}_{2} \mathrm{PO}_{4}\right)_{2} \cdot 2 \mathrm{H}_{2} \mathrm{O}$ it was established the dependence of electrical conductivity of its partial dehydration products on the given temperature treatment duration. This 


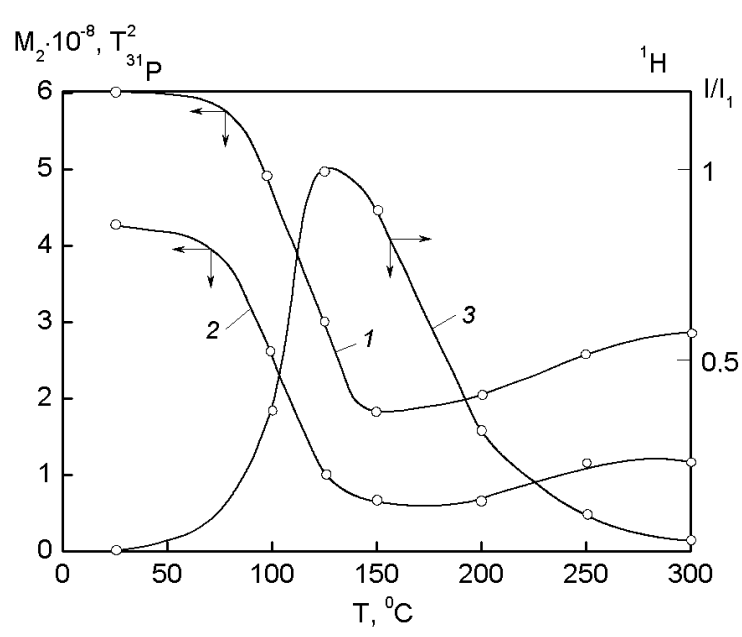

Fig. 2. Correlation of research results of heat treatment products of $\mathrm{Co}_{1-\chi} \mathrm{Zn}_{x}\left(\mathrm{H}_{2} \mathrm{PO}_{4}\right)_{2} \cdot 2 \mathrm{H}_{2} \mathrm{O}$ by $\mathrm{PMR}$ and ${ }^{31} \mathrm{P}$ NMR methods $(1-$ width and 2 - the second point in the NMR spectrums, and 3 - the intensity of the narrow component in the PMR spectrums).

made it possible analyzes the temporary operating mode of the solid electrolyte. For this purpose the sample of dihydrophosphate was heated up to $140^{\circ} \mathrm{C}$, this temperature corresponds to the maximum value of $\sigma$; it was maintained for $5 \mathrm{~h}$, regularly fixing the electrical conductivity value. The data obtained (Table 2) showed that at $140^{\circ} \mathrm{C}$ the sample keeps the high proton conductivity for $5 \mathrm{~h}$.

To determine the contribution of protons of the crystalline hydrated water molecules into the changes of proton conductivity it has been studied the temperature dependence of the electrical conductivity of dehydrated dihydrophosphate of composition $\mathrm{CO}_{0.5} \mathrm{Zn}_{0.5}\left(\mathrm{H}_{2} \mathrm{PO}_{4}\right)_{2}$, dried over $\mathrm{P}_{2} \mathrm{O}_{5}$ to remove two water molecules. According to received polytherms of the conductivity (Fig. 1), main character varying of $\sigma$ of the sample during heating and order of magnitude of $\sigma$ are similar to those for the air-dried dihydrate $\mathrm{Co}_{0.5} \mathrm{Zn}_{0.5}\left(\mathrm{H}_{2} \mathrm{PO}_{4}\right)_{2} \cdot 2 \mathrm{H}_{2} \mathrm{O}$. Significant increase in the conductivity of $\mathrm{Co}_{0.5} \mathrm{Zn}_{0.5}\left(\mathrm{H}_{2} \mathrm{PO}_{4}\right)_{2}$ is fixed in the temperature range of $70-90^{\circ} \mathrm{C}$ (to $3.1 \cdot 10^{-3} \mathrm{Ohm}^{-1} \mathrm{~cm}^{-1}$ ). Some differences of the temperature dependence that were set during further temperature increases up to $180^{\circ} \mathrm{C}\left(1.77 \cdot 10^{-2} \mathrm{Ohm}^{-1} \mathrm{~cm}^{-1}\right)$ are caused by some differences of processes occurring in the sample. In the temperature range from 180 to $270^{\circ} \mathrm{C}$ the conductivity value is stabilized and takes relatively high values $\left(1.47 \cdot 10^{-2}-1.96 \cdot 10^{-2} \mathrm{Ohm}^{-1} \mathrm{~cm}^{-1}\right)$.
Table 2. Dependence of electrical conductivity of $\mathrm{Co}_{0.5} \mathrm{Zn}_{0.5}\left(\mathrm{H}_{2} \mathrm{PO}_{4}\right)_{2} \cdot 2 \mathrm{H}_{2} \mathrm{O}$ on the duration of heat treatment at $140^{\circ} \mathrm{C}$

\begin{tabular}{|c|c|c||}
\hline $\begin{array}{c}\text { The duration } \\
\text { of heating, min }\end{array}$ & $R, \mathrm{Ohm}$ & $\sigma, \mathrm{Ohm}^{-1} \mathrm{~cm}^{-1}$ \\
\hline 5 & 15.10 & $8.11 \cdot 10^{-3}$ \\
20 & 10.74 & $1.14 \cdot 10^{-2}$ \\
50 & 10.54 & $1.16 \cdot 10^{-2}$ \\
75 & 10.30 & $1.19 \cdot 10^{-2}$ \\
90 & 10.25 & $1.19 \cdot 10^{-2}$ \\
120 & 10.87 & $1.13 \cdot 10^{-2}$ \\
180 & 12.57 & $9.74 \cdot 10^{-3}$ \\
240 & 23.20 & $5.28 \cdot 10^{-3}$ \\
300 & 47.20 & $2.59 \cdot 10^{-3}$ \\
\hline
\end{tabular}

Analysis of the data together with the results of the research of products of $\mathrm{Co}_{0.5} \mathrm{Zn}_{0.5}\left(\mathrm{H}_{2} \mathrm{PO}_{4}\right)_{2} \cdot 2 \mathrm{H}_{2} \mathrm{O}$ thermolysis [6] suggests that those responsible for the appearance of electric current, when heated dihydrophosphate, are protons of $\mathrm{P}-\mathrm{OH}$ phosphate groups. However, the presence of hydrogen bonds in the structure of $\mathrm{CO}_{0.5} \mathrm{Zn}_{0.5}\left(\mathrm{H}_{2} \mathrm{PO}_{4}\right)_{2} \cdot 2 \mathrm{H}_{2} \mathrm{O}$ does not exclude the partial change in the overall mobility of the protons by moving them along the line $\mathrm{H}$-bond, as it is observed while heating hydrated $\mathrm{CO}_{0.5} \mathrm{Zn}_{0.5}\left(\mathrm{H}_{2} \mathrm{PO}_{4}\right)_{2} \cdot 2 \mathrm{H}_{2} \mathrm{O}$ up to $85-90^{\circ} \mathrm{C}$.

Polytherms of the sample conductivity that were obtained by heating of $\mathrm{Co}_{0.5} \mathrm{Zn}_{0.5}\left(\mathrm{H}_{2} \mathrm{PO}_{4}\right)_{2} \cdot 2 \mathrm{H}_{2} \mathrm{O}$ up to $300^{\circ} \mathrm{C}$ (according to [6], it appears to be cyclotetraphosphate - condensed phosphate with cyclic structure of anion) and leaved after cooling for $24 \mathrm{~h}$ in dry (over $\mathrm{P}_{2} \mathrm{O}_{5}$ ) and in humid atmosphere (relative humidity $80 \%$, $20^{\circ} \mathrm{C}$ ), showed the sharply different temperature dependence of conductivity (Fig. 1). Thus, the relatively low maximum values of conductivity of cyclotetraphosphate sustained in the dry atmosphere $\left(1.04 \cdot 10^{-3}-\right.$ $1.52 \cdot 10^{-3} \mathrm{Ohm}^{-1} \mathrm{~cm}^{-1}$ ) are recorded in the temperature range of $140-240^{\circ} \mathrm{C}$. For cyclotetraphosphate sustained in the humid atmosphere the maximum value of $\sigma$ is much higher, at $1.01 \cdot 10^{-2}-1.18 \cdot 10^{-2} \mathrm{Ohm}^{-1} \mathrm{~cm}^{-1}$ at $70-100^{\circ} \mathrm{C}$. With increasing of the heating temperature up to $260^{\circ} \mathrm{C}$ the value of $\sigma$ is almost stabilized at the level of $7.51 \cdot 10^{-3}-$ $9.57 \cdot 10^{-3} \mathrm{Ohm}^{-1} \mathrm{~cm}^{-1}$. The enhanced conductivity of cyclotetraphosphate sustained in the humid atmosphere promotes it partial hydrolysis with formation of the polyphos- 
phates linear structure containing the $\mathrm{P}-\mathrm{OH}$ groups. Protons of these groups cause appearance of the electric current in the dehydrated products of heat treatment of the solid solution of dihydrophosphates of general formula $\mathrm{Co}_{1-x} \mathrm{Zn}_{x}\left(\mathrm{H}_{2} \mathrm{PO}_{4}\right)_{2} \cdot 2 \mathrm{H}_{2} \mathrm{O}(0<x<1.0)$.

The relatively high values of electrical conductivity of the solid solution of Co(II)-Zn dihydrophosphates and products of their thermolysis provided the basis to test them as sensing elements in the gas analytical instruments developed by Vernadsky Institute of General and Inorganic Chemistry of the National Academy of Sciences of Ukraine. According to our data, the greatest efficiency showed products of the thermal treatment of $\mathrm{Co}_{1-x} \mathrm{Zn}_{x}\left(\mathrm{H}_{2} \mathrm{PO}_{4}\right)_{2} \cdot 2 \mathrm{H}_{2} \mathrm{O}$ $(0<x<1.0)$, obtained at $130-260^{\circ} \mathrm{C}$.

\section{Conclusions}

The solid solution of $\mathrm{Co}(\mathrm{II})-\mathrm{Zn}$ dihydrophosphates of composition $\mathrm{Co}_{1-x} \mathrm{Zn}_{x}\left(\mathrm{H}_{2} \mathrm{PO}_{4}\right)_{2} \cdot 2 \mathrm{H}_{2} \mathrm{O}$ $(0<x<1.0)$ and products of their partial or complete dehydration have considerable proton conductivity (from 1.01.10 ${ }^{-2}-$ $1.18 \cdot 10^{-2} \mathrm{Ohm}^{-1} \mathrm{~cm}^{-1}$ up to $7.51 \cdot 10^{-3}$ $9.57 \cdot 10^{-3} \mathrm{Ohm}^{-1} \mathrm{~cm}^{-1}$ ) in a wide temperature range $\left(80-270^{\circ} \mathrm{C}\right)$.

Analyzing the PMR and NMR 31P spectra of heat treatment products of $\mathrm{Co}(\mathrm{II})-\mathrm{Zn}$ dihydrophosphates, we have found that the main contribution to the proton conductivity make the mobile protons of $\mathrm{P}-\mathrm{OH}$ groups of the phosphate anion and the protons of free phosphoric acid produced as the intermediate products of thermolysis. The contribution of the protons of the crystalline hydrate water is minimal.

The possibility of using of the solid solution of Co(II)-Zn dihydrophosphates and products of their thermolysis as sensing elements in gas analytical instruments developed by Vernadsky Institute of General and Inorganic Chemistry of the National Academy of Sciences of Ukraine is established.

\section{References}

1. N.P.Uvarov, Composite Solid Electrolytes, Soran, Novosibirsk (2008) [in Russian].

2. T.Kanazava, Inorganic Phosphorus Materials, Naukova Dumka, Kiev (1998) [in Russian].

3. V.N.Makatun, Chemistry of Inorganic Hydrates, Nauka i Tehnika, Moscow (1985) [in Russian].

4. I.A.Stenina, M.G.Zhizhin, B.I.Lazoryak, Mater. Res. Bull., 44, 1608 (2009).

5. N.M.Antraptseva, L.N.Shchegrov, I.G.Ponomareva, J.Inorg. Chem., 51, 1493 (2006).

6. N.Antraptseva, N.Tkacheva, Scientific Works, Plovdiv University of Food Technologies, LIX, 41 (2012).

7. UA Patent, 85588 (2013).

8. A.Boudjada, A.Durif, J.Apll.Crystallogr., 12, 609 (1979). 